\title{
Effect of Inmersion Desinfection with $0.5 \%$ Sodium Hypochlorite and 2\% Glutaraldehyde on Alginate and Silicone: Microbiology and SEM Study
}

\author{
Efecto de la Desinfección en Inmersión con $0,5 \%$ de Hipoclorito Sódico y \\ Glutaraldehído al $2 \%$ sobre Alginato y Silicona: Estudio de la Microbiología y SEM
}

\author{
J. Bustos*; R. Herrera**; U. González ${ }^{\star * *}$; A. Martínez ${ }^{\star * * *}$ \& A. Catalán ${ }^{\star * * * *}$
}

BUSTOS, J.; HERRERA, R.; GONZÁLEZ, U.; MARTíNEZ, A. \& CATALÁN, A. Effect of inmersion desinfection with 0,5\% sodium hypochlorite and $2 \%$ glutaraldehyde on alginate and silicone: Microbiology and SEM study. Int. J. Odontostomat., 4(2):169-177, 2010.

ABSTRACT: The disinfection of dental impression materials has become an essential topic of universal concern, as it may be the first instance of microbial contamination during dental care. The purpose of this study is twofold: To determine the effectiveness of disinfection with $0.5 \%$ sodium hypochlorite and $2 \%$ glutaraldehyde solutions in irreversible hydrocolloid (alginate) and silicone impressions and to analyze the effect of disinfection on surface quality with a scanning electronic microscope. A total of 32 impressions (16 made of irreversible hydrocolloid and 16 made of silicone) were taken from maxillary dentate patients. Samples of $1 \mathrm{~cm} 2$ ( 80 , irreversible hydrocolloid, 80 silicone) were obtained and distributed in ten groups: alginate in no disinfectant (control group $1, \mathrm{AL}$ ), alginate in $0.5 \%$ sodium hypochlorite $(\mathrm{NaOCl})$ for $5(\mathrm{AH} 5)$ and 10 minutes $(\mathrm{AH} 10)$, alginate in $2 \%$ glutaraldehyde for 5 (AG5) and 10 minutes (AG10), silicone in no disinfectant (control group 2), silicone in $0.5 \% \mathrm{NaOCl}$ for 5 (SH5) and 10 minutes (SH10), and silicone in 2\% glutaraldehyde for 5 (SG5) and 10 minutes (SG10). Each sample was divided into two segments (one for the microbiological and one for the SEM study). Microbiological samples were planted on blood agar, Mac Conkey agar, and Sabouraud agar, and identification was made by Gram's stain. The samples were then processed by an SEM. Immersion in the $5 \% \mathrm{NaOCl}$ and $2 \%$ glutaraldehyde for 10 minutes completely eliminated bacteria in the impressions, compared with the control group ( $\mathrm{P}=0.000004)$. Immersion in $0.5 \% \mathrm{NaOCl}$ and $2 \%$ glutaraldehyde for 5 and 10 minutes significantly inhibited bacterial growth in both the irreversible hydrocolloid and silicone impressions compared with control group $(\mathrm{P}<0.05)$. However, in the SEM study, immersion in both disinfectant solutions for 5 and 10 minutes did not significantly affect the surface quality of the irreversible hydrocolloid and silicone impressions compared with immersion in the non-disinfectant samples. Impression materials retain bacteria. Immersion in $0.5 \% \mathrm{NaOCl}$ solution and $2 \%$ glutaraldehyde for 5 minutes can successfully disinfect irreversible hydrocolloid and silicone impressions. The results showed that it is prudent for either the operator or the technician to treat impressions for 5 minutes by immersion in $0.5 \% \mathrm{NaOCl}$ or $2 \%$ glutaraldehyde to reduce the level of bacterial contamination and hence the risk of cross infection.

KEY WORDS: disinfection, irreversible hydrocolloid, silicone, impression, $0.5 \%$ sodium $\mathrm{NaOCI}, 2 \%$ glutaraldehyde.

\section{INTRODUCTION}

The disinfection of dental impression materials has become an essential topic of universal concern (ADA, 1991, 1996; Kohn et al., 2003; Muller-Bolla et al., 2004) because of the potential for cross-infections from microbial contaminated dental impressions to dental staff (Beyerle et al., 1994; Leung \& Schonfeld,

* Graduate Student, Oral Rehabilitation Prosthetic Mention, Department of Restorative Dentistry, Faculty of Dentistry, Universidad de Concepción, Concepción, Chile.

** Professor, Department of Microbiology, Faculty of Microbiological Science, Universidad de Concepción, Concepción, Chile.

*** U. González, Professor, Statistics Department of Physical and Mathematical Sciences Faculty, Universidad de Concepción, Concepción, Chile.

**** Professor, Oral Pathology, Department of Oral Pathology, Faculty of Dentistry, Universidad de Concepción, Concepción, Chile.

***** MSC Professor and Head of Oral Rehabilitation Prosthetic Mention Postgraduate , Department of Restorative Dentistry, Faculty of Dentistry, Universidad de Concepción, Concepción, Chile

This study was supported by DIUC Grant No. 205.102.009-1-0. Universidad de Concepción, Concepción, Chile. 
BUSTOS, J.; HERRERA, R.; GONZÁLEZ, U.; MARTíNEZ, A. \& CATALÁN, A. Effect of inmersion desinfection with 0,5\% sodium hypochlorite and $2 \%$ glutaraldehyde on alginate and silicone: Microbiology and SEM study. Int. J. Odontostomat., 4(2):169-177, 2010.

1983; Powell et al., 1990; Egusa et al., 2008). It is generally understood that once an impression is made, saliva, blood, oral bacteria, fungus, and viruses remain on the surfaces of impressions and persevere thereon during the ensuing period (Egusa et al.; Samaranayake et al., 1991; Soufu et al., 2002; AlJabrah et al., 2006).

The American Dental Association (ADA) and the Centers for Disease Control and Prevention (CDC) have suggested methods for disinfecting dental impressions, including immersion in or spraying with a disinfectant (ADA, 1991, 1996). Both techniques have been shown to be effective at disinfecting the surface of the impression material (Rueggeberg et al., 1992; Johnson et al., 1998; Al-Omari et al., 1998; Westernholm et al., 1992; Schwartz et al., 1996; Lepe et al., 2002; Vandewalle et al., 1994).

An effective disinfectant for an irreversible hydrocolloid impression recommended by the American Dental Association (ADA, 1996), is sodium hypochlorite $(\mathrm{NaOCl})$, diluted $1: 10$ and immersed for ten minutes. However, some authors claim that $\mathrm{NaOCl}$ solutions are naturally unstable, and, if used for disinfecting, they should be made fresh daily (Cottone \& Molinari, 1987). Other studies, which used a variety of $\mathrm{NaOCl}$ concentrations and times during the disinfection of dental impressions (Schwartz et al.; Yilmaz et al., 2007; Walker et al., 2007; Martin et al., 2007), have suggested that chlorine solutions are actually stable over long periods of time under varying conditions, storage, and use (Pappalardo et al., 1986; Gerhardt \& Williams, 1991).

One of the most commonly used disinfectants from the aldehyde group, glutaraldehyde, a bactericidal, a virucidal, and a fungicidal, has been found to be efficacious as a disinfectant for alginate and silicone impressions (Yilmaz et al.).

Several studies have tested the effects of diverse disinfectants on the dimensional stability of irreversible hydrocolloid and silicone impressions (Johnson et al.; Yilmaz et al.; Tullner et al., 1988). Nevertheless, few studies have evaluated the effect of disinfection on the surface quality of impressions. Thus, this study has a dual purpose of determining the effectiveness of disinfection with $0.5 \% \mathrm{NaOCl}$ and $2 \%$ glutaraldehyde solutions on irreversible hydrocolloid and silicone impressions and analyzing structural changes at the surface level with a scanning electronic microscope.

\section{MATERIAL AND METHOD}

This study examined 102 dentate patients that visited the Prosthodontic Department of the School of Dentistry at the Universidad de Concepción in Concepción, Chile. The patients were selected because the microbial load on impression materials for such patients is significantly greater than that for edentulous patients (Samaranayake et al.). Of the 102 patients, 16 dentate, non-smoking, non-diabetic, nonhypertense, non-xerostomic patients not being treated with antibiotics were selected. After the subjects gave their informed consent, the study was approved by the Ethics Committee of the Universidad de Concepción.

For each patient, 2 complete maxillary impressions were taken, 16 in irreversible hydrocolloid (Jeltrate without clorhexidine, Dentsply, Rio de Janeiro, Brazil) mixed with sterile water and 16 in silicone for condensation Speedex Coltene (Whaladent Inc. New Jersey, USA). The risk of removing microorganisms during the first impression was eliminated by allowing 72 hours between the two impressions taken from each patient. The impression materials were proportioned, mixed, and manipulated according to the manufacturer's recommendations.

The impressions were removed from patients' mouths but not washed, and then samples were made ten minutes after the impressions were taken.

For each impression, five samples were removed from the palate impression in the form of $1 \mathrm{~cm}^{2}$ aseptically with the help of a sterile blade. Each separate section was placed in a sterile container and exposed to two disinfectant solutions: $0.5 \% \mathrm{NaOCl}$ and $2 \%$ glutaraldehyde and a control group (not disinfected).

A total of 160 samples were randomly divided into ten 16-specimen groups and submitted to the following immersion disinfection treatments: $A L=$ (control group1), irreversible hydrocolloid not disinfected; $\mathrm{AH} 5=$ irreversible hydrocolloid $0.5 \%, \mathrm{NaOCl} 5$ minutes; $\mathrm{AH} 10=$ irreversible hydrocolloid, $0.5 \% \mathrm{NaOCl} 10$ minutes; AG5 = irreversible hydrocolloid, $2 \%$ glutaraldehyde 5 minutes; AG10 = irreversible hydrocolloid, $2 \%$ glutaraldehyde 10 minutes; SI (control group 2) = silicone not disinfected; $\mathrm{SH} 5=$ silicone $0.5 \% \mathrm{NaOCl} 5$ minutes; $\mathrm{SH} 10=$ silicone $0.5 \% \mathrm{NaOCl}$ 10 minutes;. SG5 $=$ silicone $2 \%$ glutaraldehyde 5 minutes; and SG10 = silicone $2 \%$ glutaraldehyde, 10 minutes. After the disinfection procedure, each sample 
BUSTOS, J.; HERRERA, R.; GONZÁLEZ, U.; MARTíNEZ, A. \& CATALÁN, A. Effect of inmersion desinfection with 0,5\% sodium hypochlorite and 2\% glutaraldehyde on alginate and silicone: Microbiology and SEM study. Int. J. Odontostomat., 4(2):169-177, 2010.

was divided into two segments, one for microbiological study and the other for scanning electronic microscopic (SEM) study.

Microbiological Study. Following immersion into the disinfectant solution, each sample of the impression material (irreversible hydrocolloid or silicone) was transferred to a sterile containment tube with $0.5 \mathrm{ml}$ of reduced transport fluid (RTF) (Syed \& Loesche, 1972) and sent to the Microbiology Department of the Biological Science Faculty of the Universidad de Concepción. The samples were vortexed for five minutes to remove any suspended microorganisms contaminating the samples (Verter Mixer, type maximix 37600 ). A $0.15 \mathrm{ml}$ sample of the material wash was spread onto blood agar plates (Difco Laboratories) for isolation of cocci Gram (+) and (-), on Mac Conkey agar plates (Difco Laboratories) for isolation of bacillus Gram (-), and on Sabouraud agar plates (Difco Laboratories) for isolation of Candida spp. All the plates were incubated aerobically at $37^{\circ} \mathrm{C}$ for 48 hours. The number of colonies that appeared after incubation was expressed as CFUs (colony-forming units), and then the CFUs were counted with a Leselupe magnifying glass (TCMD-2290, Hamburg, Germany). Isolates were stained with Gram's stain and identified using standard microbiologic methods.

SEM Study. The samples were transported in a sterile petri dish, dried in a critical point dryer for 1 hour at 25o C (Memmert, Schwabach, Germany), and then mounted onto aluminum studs with silver conducting paint. Finally, the specimens were coated with gold by using a sputter-coater cathodic evaporizator (Edwards S150 Sputter Coater, MA, USA). The superficies were examined under a SEM JEOL (JSM-638 OLV, Tokyo, Japan) operating at $25 \mathrm{kV}$.

Statistical Procedures. Microbiologic data were tabulated and statistical tests performed with SPSS 12.0 (Chicago, IL, USA). Viable counts were transformed to $\mathrm{Ln}(\mathrm{CFU}+1)$ and the results presented as the mean of $\operatorname{Ln}(\mathrm{CFU}+1)$. Differences between the groups were examined using ANOVA and the MannWhitney test. The differences were considered statistically significant when $\mathrm{P}<0.05$.

\section{RESULTS}

The results showed no bacterial growth on Mac Conkey agar in the non-disinfected samples (i.e., the control group) nor in alginate and silicone impressions treated with $0.5 \% \mathrm{NaOCl}$ and $2 \%$ glutaraldehyde at 5 and 10-minute exposure times. The data from the mycological cultures tested negative for each disinfectant and control group.

Results of the microbiological cultures on blood agar for each treatment group are presented in Table I. The data showed that the number of bacteria retained in the irreversible hydrocolloid (mean CFU $=0.71 \times 103 \pm 1.05 \times 103)$ samples was higher than it was in silicone (mean CFU $=0.41 \times 103 \pm 0.57 \times 103$ ), shown in Figs. 1 and 2. Immersion in the $5 \% \mathrm{NaOCl}$ and $2 \%$ glutaraldehyde after a 10 -minute exposure time was $100 \%$ successful in eliminating bacteria carried by the irreversible hydrocolloid and silicone impressions. A highly significant inhibition in bacterial growth was found in the AH5, AH10, AG5, and AG10 groups when they were compared with $A L$ control group $1(P=0.000$, using the Mann-Whitney test), shown in Figure 1, and the SH5, SH10, SG5 and SG10 groups, when they were compared with SI control group 2 $(P=0.000$, Mann-Whitney test), shown in Fig. 2. However, the AH5, AH10, and AG5 groups did not significantly differ from the $A G 10$ group $(P>0.05)$, shown in Figure 1, and the SH5, SH10, and SG5 groups did not significantly differ from SG10 group $(P>0.05)$, shown in Fig. 2.

The representative SEM microphotographs exhibited no differences at the surface level of the irreversible hydrocolloid and silicone treated with $0.5 \%$ $\mathrm{NaOCl}$ or $2 \%$ gluteraldehyde in both immersion

Table I. Activity of $0.5 \% \mathrm{NaOCL}$ and $2 \%$ Glutaraldehyde on bacteria expressed as mean with Standar Desviation of colonyforming units (CFUs).

\begin{tabular}{|c|c|c|c|c|}
\hline Control Group & $0.71 \times 10^{3}$ & $\pm 1.05 \times 10^{5}$ & $0.41 \times 10^{3}$ & $\pm 0.57 \times 10^{5}$ \\
\hline $0.5 \% \mathrm{NaOCl}$ Immersion 5-minutes & $0.017 \times 10^{3}$ & $\pm 0.22 \times 10^{3}$ & $0.0125 \times 10^{3}$ & $\pm 0.03 \times 10^{5}$ \\
\hline $0.5 \% \mathrm{NaOCl}$ Immersion $10-$ minutes & 0 & & 0 & \\
\hline 2\% Glutaraldehyde Immersion 5-minutes & $0.020 \times 10^{3}$ & $\pm 0.04 \times 10^{3}$ & 0 & \\
\hline $2 \%$ Glutaraldehyde Immersion 10 -minutes & 0 & & 0 & \\
\hline
\end{tabular}


exposure times. Additionally, no morphological differences were observed at the surface between non-disinfected (control group) and disinfected samples (Figs. 3 and 4).

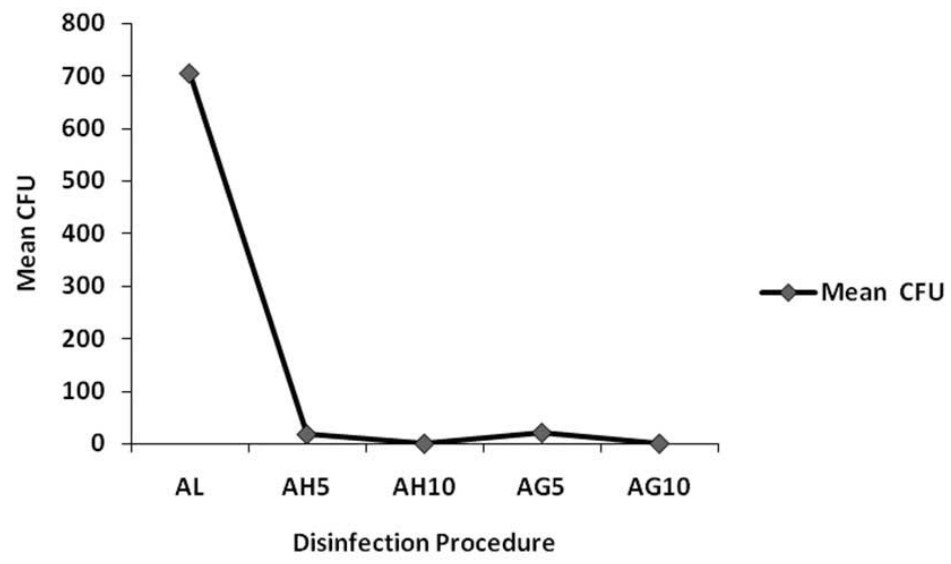

Fig. 1. Comparison of the efficacy of $0.5 \% \mathrm{NaOCl}$ and $2 \%$ glutaraldehyde in inhibiting bacteria growth on irreversible hydrocolloid impression. Mean of bacteria CFU with respect of 5 and 10-minutes immersion. Results are expressed as Ln (CFU+1).

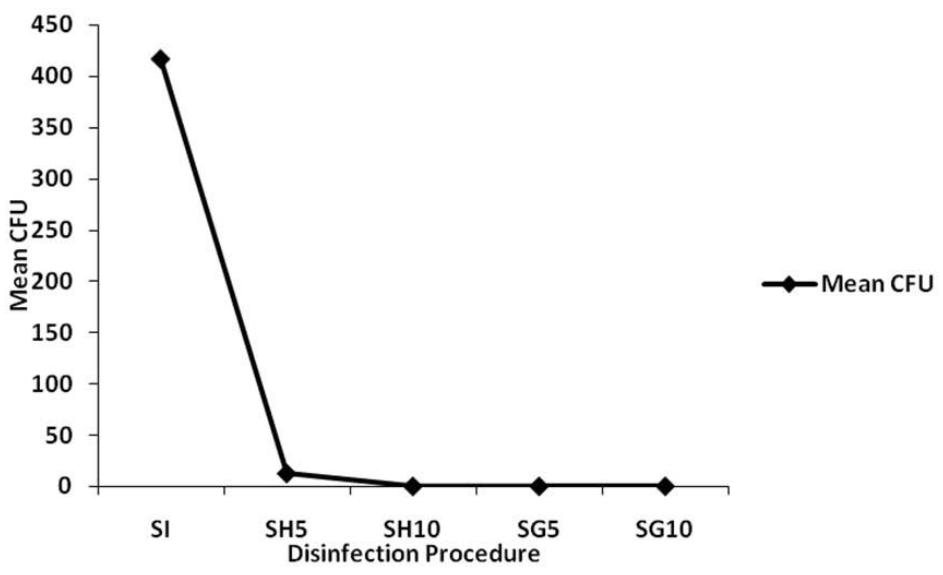

Fig. 2. Comparison of the efficacy of $0.5 \%$ NaOCL and $2 \%$ glutaraldehyde in inhibiting bacteria growth on silicone impression. Mean of bacteria CFU with respect of 5 and 10-minutes immersion. Results are expressed as Ln (CFU+1).

\section{DISCUSSION}

Several studies have highlighted the importance of the disinfection of dental impressions to prevent the possible transmission of infectious diseases (Leung \& Schonfeld; Egusa et al.; Samaranayake et al.; Soufu et al.; Al- Jabrah et al.). This study showed that the number of bacteria retained on the irreversible hydrocolloid sample is higher than on the silicone sample. One explanation for this finding may be the irregular topographical features of alginate compared with smooth surface silicone, as shown in the SEM images. Similar microbial contamination of dental impressions has also been documented by other studies (Egusa et al.; Samaranayake et al.; Soufu et al.; Al- Jabrah et al.). Egusa et al. found impressions and gypsum casts contaminated with numerous microbes, including pathogens such as Candida, MRSA, and $P$. aeruginosa. Thus, this study, as well as previous studies (ADA, 1991, 1996; Kohn et al.; Muller-Bolla et al.; Beyerle et al.; Powell et al.; Samaranayake et al.; Soufu et al.; Al- Jabrah et al.) that have described disinfection methods, suggests that dentists, inoffice dental auxiliaries, and dental technicians exercise care and control when disinfecting impression materials in order to prevent the transmission of diseases.

In addition, the irreversible hydrocolloid impressions immersed for 5 and 10 minutes in $0.5 \% \mathrm{NaOCl}(\mathrm{AH} 5, \mathrm{AH} 10)$ and for 5 and 10 minutes in $2 \%$ glutaraldehyde (AG5, AG10) exhibited significantly higher inhibition in microbial growth than AL control group 1 . However, groups AH5, AH10, AG5 did not differ significantly from group AG10. Similar to this study, several other studies have found various materials capable of completely removing microorganisms from impression materials following exposure to various disinfection solutions (Samaranayake et al.; Al- Jabrah et al.; Al-Omari et al.; Weterholm et al.; Schwartz et al.; Vandewalle et al.). However, unlike the sampling procedures of these studies, this study subjected both the surface and body of the impression to disinfection. Unless it is established that the impression has absorbed the disinfectant, below realistic clinical conditions, only $0.5 \% \mathrm{NaOCl}$ or $2 \%$ glutaraldehyde will actively kill bacteria infecting the surface of the impression.

Our data also revealed that the silicone specimens immersed in both $5 \% \mathrm{NaOCl}$ for 10 minutes and $2 \%$ glutaraldhyde for 5 and 10 minutes were able to completely eliminate the bacteria absorbed in the impressions. In addition, while SH5, SH10, SG5 and SG10 groups significantly differed from SI control group 2, SH5, SH10, SG5 groups did not significantly differ from the SG10 group. 
BUSTOS, J.; HERRERA, R.; GONZÁLEZ, U.; MARTíNEZ, A. \& CATALÁN, A. Effect of inmersion desinfection with 0,5\% sodium hypochlorite and 2\% glutaraldehyde on alginate and silicone: Microbiology and SEM study. Int. J. Odontostomat., 4(2):169-177, 2010.
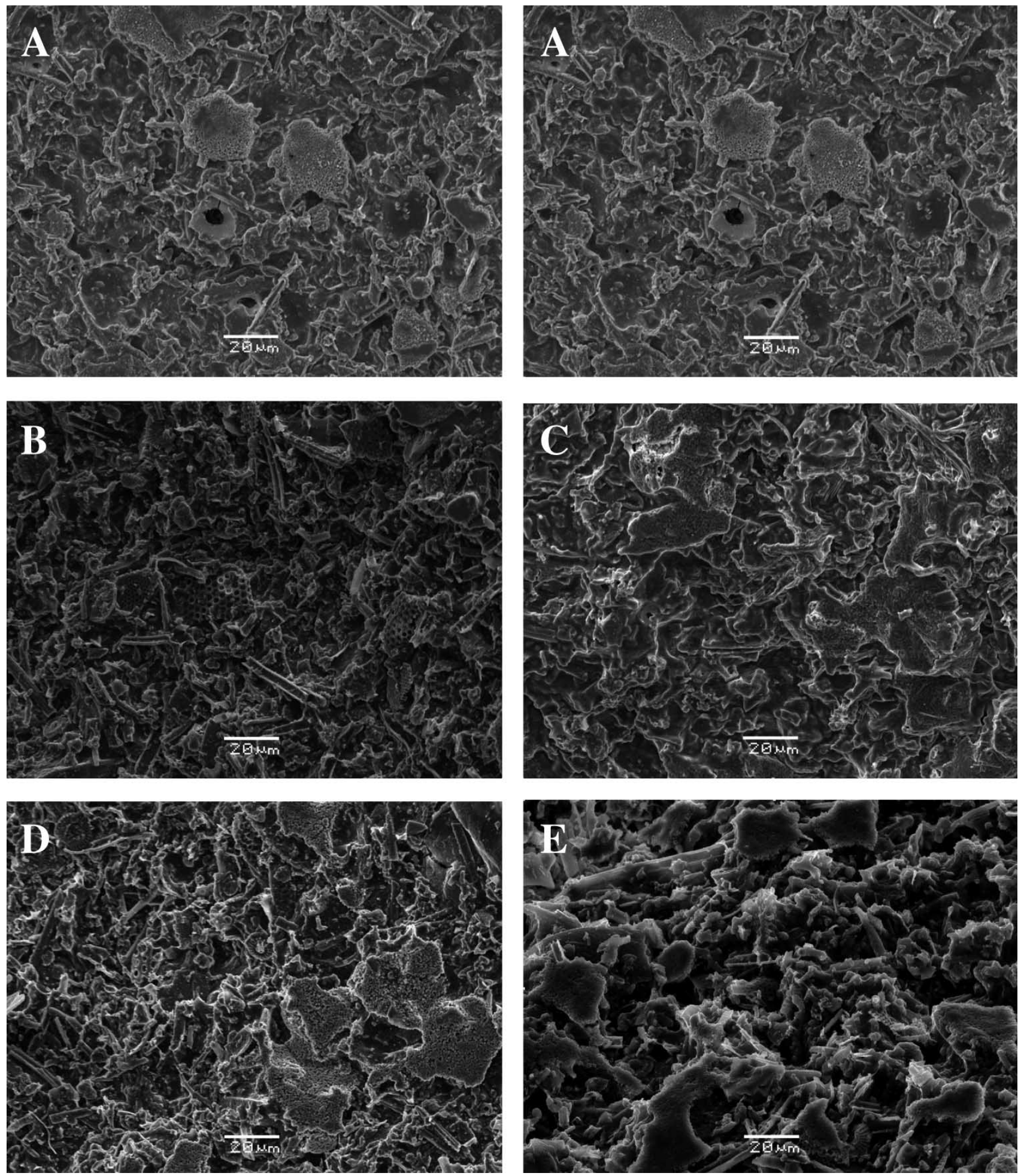

Fig. 3. Representative SEM micrographs of irreversible hydrocolloid surfaces: (A) control (no disinfection); (B) 5-minutes $0.5 \% \mathrm{NaOCl}$; (C) 10-minutes $0.5 \% \mathrm{NaOCL}$; (D) 5 -minutes; $2 \%$ glutaraldehyde; and (E) 10 -minutes $2 \%$ glutaraldehyde. Original magnification $\times 700$. 

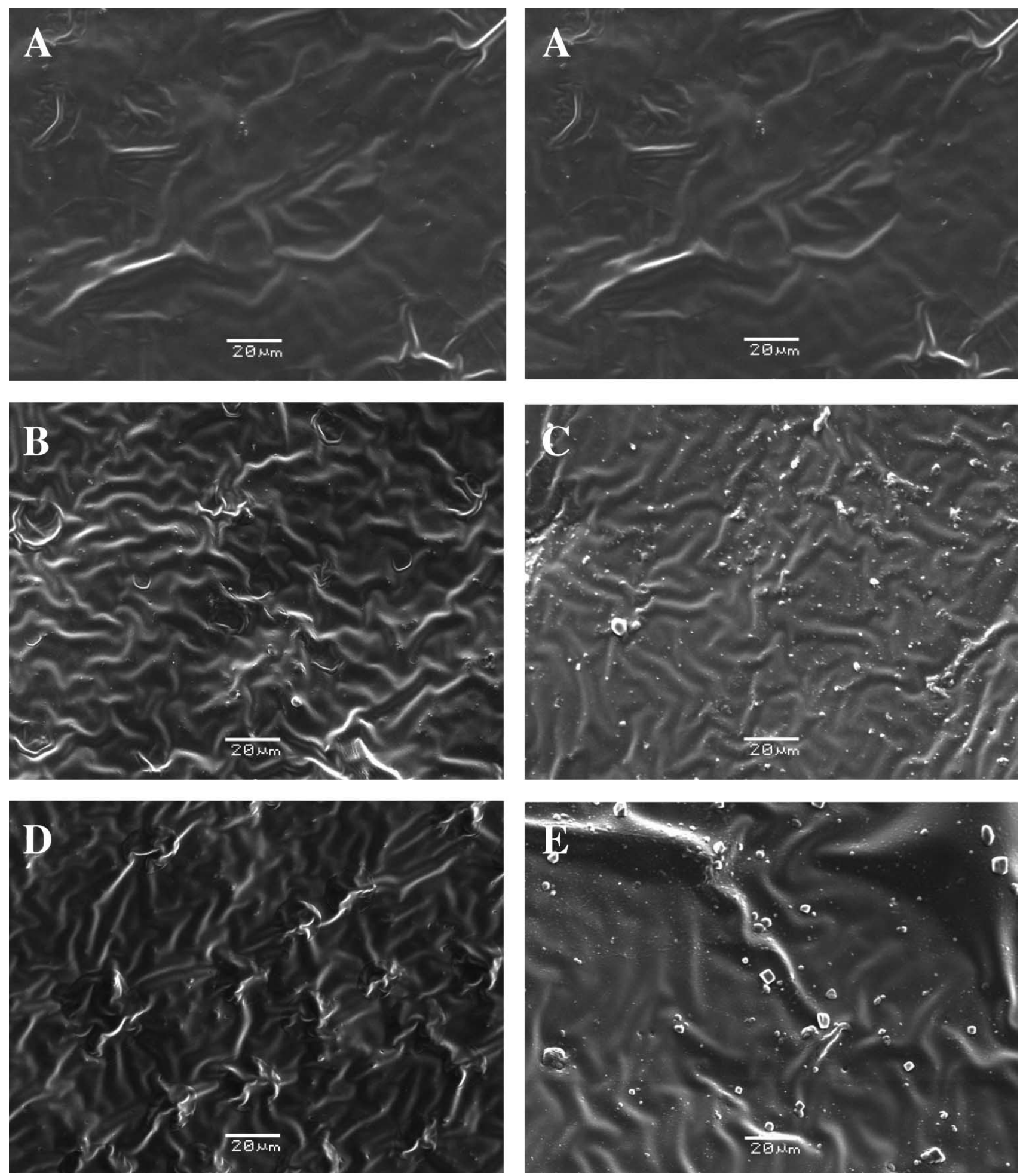

Fig. 4. Representative SEM images of Silicone surfaces: (A) control (no disinfection); (B) 5 -minutes $0.5 \% \mathrm{NaOCl}$; (C) 10 minutes $0.5 \% \mathrm{NaOCL}$; (D) 5-minutes; $2 \%$ glutaraldehyde; and (E) 10-minutes $2 \%$ glutaraldehyde. Original magnification $\mathrm{x} 700$. 
BUSTOS, J.; HERRERA, R.; GONZÁLEZ, U.; MARTíNEZ, A. \& CATALÁN, A. Effect of inmersion desinfection with 0,5\% sodium hypochlorite and 2\% glutaraldehyde on alginate and silicone: Microbiology and SEM study. Int. J. Odontostomat., 4(2):169-177, 2010.

After immersion disinfection, the surface characteristics of impression materials may be altered (Walker et al.). Several studies have assessed the effect of disinfectants on the dimensional accuracy on impression materials and the reproduction of surface features directly by impression evaluations and indirectly by cast measurements (Johnson et al.; Lepe et al.; Yilmaz et al.; Walker et al.; Martin et al.; Herrera \& Merchant, 1986; Bergman et al., 1980; Tullner et al.).

The SEM characterization of irreversible hydrocolloid and silicone specimens revealed no differences at the surface level between non-disinfected and disinfected impressions. Consistent with those from other investigations that evaluated surface quality and detailed reproduction following the disinfection of impression materials, this study found no adverse surface changes with immersion disinfection (Johnson et al.; Lepe et al.; Bergman et al.). However, Walker et al. revealed that Impregm Pentasoft PE surface quality appeared to be adversely affected by increased exposure to 10 - minute $\mathrm{NaOCl}$.

It appears that specimens immersed in either $0.5 \% \mathrm{NaOCl}$ or $2 \%$ gluteraldehyde for 5 minutes effectively disinfected the irreversible hydrocolloid and silicone impressions. In addition, reducing immersion time can also minimize changes in physical properties such as dimensional stability and surface integrity. Future research may determine if these results translate to the disinfection of complete mouth impressions and whether or not steps should be taken in order to conduct an actual clinical trial.

In conclusion, according to the findings of this study, impression materials retain bacteria. However, irreversible hydrocolloid and silicone impressions can successfully be disinfected if they are immersed in either $0.5 \% \mathrm{NaOCl}$ solution or $2 \%$ glutaraldehyde for 5 minutes.

BUSTOS, J.; HERRERA, R.; GONZÁLEZ, U.; MARTÍNEZ, A. \& CATALÁN, A. Efecto de la desinfección en inmersión con $0,5 \%$ de hipoclorito sódico y glutaraldehído al $2 \%$ sobre alginato y silicona: estudio de la microbiología y SEM. Int. J. Odontostomat., 4(2):169-177, 2010.

RESUMEN: La desinfección de los materiales de impresión dental se ha convertido en un tema esencial, ya que puede ser el primer caso de contaminación microbiana durante la atención dental. El propósito de este estudio es doble: determinar la eficacia de la desinfección con hipoclorito sódico al $0,5 \%$ y $2 \%$ de glutaraldehído en soluciones de hidrocoloide irreversible (alginato) y las impresiones de silicona, para analizar el efecto de la desinfección en la calidad de la superficie con un microscopio electrónico de barrido. Un total de 32 impresiones (16 hechas de hidrocoloides irreversibles y 16 de silicona) superiores de pacientes dentados fueron estudiadas. Las muestras de $1 \mathrm{~cm} 2$ ( 80 , hidrocoloide irreversible, el 80 de silicona) fueron obtenidas y distribuidas en diez grupos: alginato sin desinfectante (grupo de control $1, \mathrm{AL}$ ), alginato en el $0,5 \%$ de hipoclorito sódico ( $\mathrm{NaOCl}$ ) durante $5(\mathrm{AH} 5)$ y 10 minutos (AH10), alginato en glutaraldehído al $2 \%$ durante 5 (GA5) y 10 minutos (AG10), silicona sin desinfectante (grupo de control 2), silicona en $0,5 \%$ de $\mathrm{NaOCl}$ durante 5 (SH5) y 10 minutos (SH10) y, en glutaraldehído al $2 \%$ durante 5 (SG5) y 10 minutos (SG10). Cada muestra se dividió en dos segmentos (uno para los análisis microbiológicos y uno para el estudio SEM). Las muestras microbiológicas se sembraron en agar sangre, agar MacConkey y agar Sabouraud, y la identificación se realizó por tinción de Gram. Las muestras fueron procesadas por un SEM. La inmersión en $5 \% \mathrm{NaOCl}$ y $2 \%$ de glutaraldehído durante 10 minutos eliminó completamente las bacterias de las impresiones, en comparación con el grupo control $(P=0,000004)$. La inmersión en $0,5 \%$ de $\mathrm{NaOCl}$ y glutaraldehído al $2 \%$ durante 5 y 10 minutos, inhibió el crecimiento de bacterias, tanto en el hidrocoloide irreversible e impresiones de silicona en comparación con el grupo control $(P<0,05)$. Sin embargo, en el estudio SEM, la inmersión en soluciones desinfectantes, tanto durante 5 minutos y 10 no afectó de forma significativa la calidad de la superficie del hidrocoloide irreversible e impresiones de silicona en comparación con la inmersión en las muestras sin desinfectante. Los materiales de impresión retiene bacterias. La inmersión en solución al 0,5\% de $\mathrm{NaOCl}$ y $2 \%$ de glutaraldehído durante 5 minutos puede desinfectar con éxito hidrocoloides irreversibles e impresiones de silicona. Los resultados mostraron que es prudente para el operador o el técnico el tratamiento de impresiones durante 5 minutos por inmersión en $0,5 \%$ de $\mathrm{NaOCl}$ o glutaraldehído al $2 \%$ para reducir el nivel de contaminación bacteriana y por lo tanto el riesgo de infección cruzada.

PALABRAS CLAVE: desinfección, hidrocoloide irreversible, silicona, impresión, 0,5\% de $\mathrm{NaOCI}$, glutaraldehído al $2 \%$. 
BUSTOS, J.; HERRERA, R.; GONZÁLEZ, U.; MARTíNEZ, A. \& CATALÁN, A. Effect of inmersion desinfection with 0,5\% sodium hypochlorite and $2 \%$ glutaraldehyde on alginate and silicone: Microbiology and SEM study. Int. J. Odontostomat., 4(2):169-177, 2010.

\section{REFERENCES}

ADA. Infection control recommendations for the dental office and the dental laboratory. ADA Council on Scientific Affairs and ADA Council on Dental Practice. J. Am. Dent. Assoc. 127(5):672-80, 1996.

ADA. American Dental Association Council on Dental Materials, Instruments and Equipment. Disinfection of impressions. J. Am. Dent. Assoc., 122:110, 1991.

Al- Jabrah, O.; Al-Shumailan, Y.; Al-Rasdan, M. Antimicrobial effect of 4 disinfectants on alginate, polyether, and polyvinyl siloxane impression materials. Clin. Oral Investig., 10:167-73, 2006.

Al-Omari, W. M.; Gly Jones, J. C. \& Hart, P. A microbiological investigation following the disinfection of alginate and addition cured silicone rubber impression materials. Eur. J. Prosthodont. Res. Dent., 6(3):97-101, 1998.

Bergman, M.; Olsson, S. \& Bergman, B. Elastomeric impression materials. Dimensional stability and surface detail sharpness following treatment with disinfection solutions. Swed. Dent. J., 4:161-7, 1980.

Beyerle, M. P.; Hensley, D. M.; Bradley, D. V. Jr.; Schwartz, R. S. \& Hilton, T. J. Immersion disinfection of irreversible hydrocolloid impressions with sodium hypochlorite. Part I: Microbiology. Int. J. Prosthodont., 7(3):234-8, 1994.

Cottone, J. A. \& Molinari, J. A. Selection for dental practice of chemical disinfectans and sterilants for hepatitis and AIDS. Aust. Dent. J., 32:368-74, 1987.

Egusa, H.; Watamoto, T.; Abe, K.; Kobayashi, M.; Kaneda, Y.; Ashida, S.; Matsumoto, T. \& Yanati, H. An analysis of the persistent presence of opportunistic pathogens on patient-derived dental impressions and gypsum casts. Int. J. Prosthodont., 21:62-8, 2008.

Gerhardt, D. E. \& Williams, H. N. Factors affecting the stability of sodium hypochlorite solutions used to disinfect dental impressions. Quintessence Int., 22:587-91, 1991.

Herrera, S. P. \& Merchant, V. A. Dimensional stability of dental impressions after immersion disinfection.
J. Am. Dent. Assoc., 113:419-22, 1986.

Johnson, G. H.; Chellis, K. D.; Gordon, G. E. \& Lepe, $X$. Dimensional stability and detail reproduction of irreversible hydrocolloid and elastomeric impressions disinfected by immersion. J. Prosthet. Dent., 79(4):446-53, 1998.

Kohn, W. G.; Collins, A. S.; Cleveland, J. L.; Harte, J. A.; Eklund, K. J.; Malvitz, D. M. \& Centers for Disease Control and Prevention (CDC). Guidelines for infection control in dental health-care settings-2003. MMWR Recomm. Rep., 52(RR-17):1-61, 2003.

Lepe, X.; Johnson, G. H.; Berg, J. C.; Aw, T. C. \& Stroh, G. S. Wettability, imbibition, and mass change of disinfected low-viscosity impression materials. J. Prosthet. Dent., 88:268-76, 2002.

Leung, R. L. \& Schonfeld, E. S. Gypsum cast as a potential source of microbial cross-contamination. J. Prosthet. Dent., 49(2):210-1, 1983.

Martin, N.; Martin, M. V. \& Jedynakiewicz, N. M. The dimensional stability of dental impression materials following immersion in disinfecting solutions. Dental Mater., 3:760-8, 2007.

Muller-Bolla, M.; Lupi-Pegurier, L.; Velly, A. M. \& Bolla, M. A survey of disinfection of irreversible hydrocolloid and silicone impressions in European Union dental schools: Epidemiologic study. Int. J. Prosthodont., 17:165-71, 2004.

Pappalardo, G. ; Tanner, F. ; Roussian, D. \& Pannatier, A. Efficacy and stability of two chlorine containing antiseptics. Drugs Exp. Clin. Res., 12:905-9, 1986.

Powell, G. L.; Runnels, R. D.; Saxon, B. A. \& Whisenant, B. K. The presence and identification of organisms transmitted to dental laboratories. J. Prosthet. Dent., 64:235-7, 1990.

Rueggeberg, F. A.; Beall, F. E.; Kelly, M. T. \& Schuster, G. S. Sodium hypochlorite disinfection of irreversible hydrocolloid impression material. J. Prosthet. Dent., 67:628-31, 1992.

Samaranayake, L. P.; Hanjan, M. \& Jennings, K. J. 
BUSTOS, J.; HERRERA, R.; GONZÁLEZ, U.; MARTíNEZ, A. \& CATALÁN, A. Effect of inmersion desinfection with 0,5\% sodium hypochlorite and 2\% glutaraldehyde on alginate and silicone: Microbiology and SEM study. Int. J. Odontostomat., 4(2):169-177, 2010.

Carriage of oral flora on irreversible hydrocolloid and elastomeric impression materials. J. Prosthet. Dent., 65(2):244-9, 1991.

Schwartz, R. S.; Hensley, D. H. \& Bradley, D. V. Jr. Immersion disinfection of irreversible hydrocolloid impression in $\mathrm{PH}$ adjusted sodium hypochlorite. Part I: Microbiology. Int. J. Prosthodont., 9(3):21722, 1996.

Syed, S. A. \& Loesche, W. J. Survival of human dental plaque flora in various transport media. Appl. Microbiol., 24:638-44, 1972.

Soufu, A.; Larsen, T.; Fiehn, N. E. \& Owall, B. Contamination level of alginate impressions arriving at a dental laboratory. Clin. Oral Investig., 6:161-5, 2002

Tullner, J. B. ; Commette, J. A. \& Moon, P. C. Linear dimensional changes in dental impressions after immersion in disinfectant solutions. J. Prosthet. Dent., 60:725-8, 1988.

Vandewalle, K. S.; Charlton, D. G.; Schwartz, R. S.; Reagan, S. E. \& Koeppen, R. G. Immersion disinfection of irreversible hydrocolloid impressions with sodium hypochlorite. Part II: Effect on gypsum. Int. J. Prosthodont., 7(4):315-22, 1994.

Walker, M. P.; Rondeau, M.; Petrie, C.; Tasca, A. \& Williams, K. Surface quality and long-term dimensional stability of current elastomeric impression materials after disinfection. J. Prosthodont., 16:34351, 2007.

Westerholm, H. S. 2nd.; Bradley, D. V. Jr. \& Schwartz, R. S. Efficacy of various spray disinfection on irreversible hydrocolloid impressions. Int. J. Prosthodont., 5(1):47-54, 1992.

Yilmaz, H.; Aydin, C.; Gul, B.; Yilmaz, C. \& Semiz, M. Effect of disinfection on the dimensional stability of polyether impression materials. J. Prosthodont., 16:473-9, 2007.
Correspondence to:

Dr. Alfonso Catalán, DDS

Faculty of Dentistry

Universidad de Concepción

Roosevelt 1550

Concepción - CHILE

Phone: 5641204481

Fax: 5641203585

Email: acatalan@udec.cl

Received : 22-12-2009

Accepted : 14-04-2010 
